\section{Serological studies in asymptomatic congenital cytomegalovirus infection}

Immunological abnormalities have been described in patients with cytomegalovirus mononucleosis or with post-perfusion syndrome due to cytomegalovirus (CMV) (Wager et al., 1968; Klemola et al., 1969; Kantor et al., 1970). These abnormalities include the development of cryoglobulinaemia, elevation or depression of serum immunoglobulin levels, and the appearance of humoral autoantibodies, including rheumatoid factor, antinuclear antibody, anti-red cell antibodies, and cold agglutinins. The mechanism whereby the viral infection induces immunological abnormalities is unclear, though similar serological abnormalities may accompany other infectious diseases such as infectious mononucleosis (Wager et al., 1968).

Cases of neonatal cytomegalic inclusion disease may show serious damage to the nervous system or liver (Stern and Tucker, 1965) and these patients have raised serum IgM and IgA levels (McCracken and Shinefield, 1965). However, it is now known that as many as 0.5 to $1 \%$ of babies are born excreting CMV after primary infection of the mother during pregnancy; the majority of these congenital infections are asymptomatic, though the infants may excrete the virus into the throat and urine for years after birth. The mothers may also excrete virus, without symptoms, during the pregnancy and may continue to do so for several months after term (Weller, 1971).

It would be of interest to know whether these clinically silent CMV carrier states of pregnant women and neonates are characterized by the same serological alterations found in patients with overt CMV disease. We report such studies in asymptomatic mothers and babies who had serum anti-CMV antibodies, and most of whom were excreting the virus in their urine.

\section{Materials and methods}

Thirteen mothers and 11 infants were studied, including parallel studies on 8 mothers with their newborn babies. Sera were collected from 9 newborn infants; the other 2 infants were tested at 7 and 11 months. Mothers' sera were obtained during the third trimester of pregnancy or soon after delivery. At the time of serum collection all except 1 mother and 1 unrelated infant were shown to be excreting CMV in their urine.

Immunological studies. Serum immunoglobulins were measured by radial immunodiffusion in commercial agar-antibody plates*; immunoglobulin standards were those provided by the manufacturers. Normal values ( \pm 2 SD) for adults in our laboratory were IgG 1090 $( \pm 490) \mathrm{mg} / 100 \mathrm{ml}, \mathrm{IgA} 190( \pm 140) \mathrm{mg} / 100 \mathrm{ml}$, and IgM $130( \pm 90) \mathrm{mg} / 100 \mathrm{ml}$. Normal levels for children expressed as percentages of normal adult values were determined as described by Stiehm and Fudenberg (1966).

Rheumatoid factor activity was detected using commercial latex particles ${ }^{\star}$ coated with human aggregated IgG and sheep red cells sensitized with rabbit $\gamma$-globulin. Latex agglutination titres greater than 1:40 and nonheterophile sensitized sheep cell titres greater than 1:2 were considered abnormal.

Antinuclear antibody was detected by an indirect immunofluorescent test using fluorescein-conjugated goat antiserum to human IgG and peripheral blood leucocytes as substrate.

Cold agglutinins were measured with type $O$ $\mathbf{R h}+$ adult erythrocytes. Each serum was warmed at $37{ }^{\circ} \mathrm{C}$ for 2 hours, centrifuged, and the clear supernate placed at $4{ }^{\circ} \mathrm{C}$ for 72 hours and examined for the presence of cryoprecipitates.

Serum complement-fixing antibody titres to $\mathrm{CMV}$ were determined in microtitre plates with cell-associated antigen prepared from Ad 169 virus; the patient's serum specimens were inactivated at $56{ }^{\circ} \mathrm{C}$ for 30 minutes before testing (Stern and Elek, 1965).

\section{Results}

Immunological abnormalities were detected in only 3 infants and 1 of their mothers; 2 other mothers showed some abnormal features (Table). In one infant (Case 3) all serum immunoglobulins were raised, together with an antinuclear antibody titre of 1:16. Another (Case 11) had a raised IgM concentration associated with a positive sheep cell agglutination titre of $1: 4$. The third infant (Case 8), together with her mother (Case 8 ), had positive tests for rheumatoid factor; latex and sensitized sheep cell agglutination titres were 1:40 and 1:4, respectively, in the infant, and a latex titre of $1: 160$ was present in the mother. 1 mother (Case 2) had

\footnotetext{
^Hyland Immunoplates, Calif., U.S.A.
} 
TABLE

Immunological abnormalities in 13 mothers and 11 infants with asymptomatic cytomegalovirus infection

\begin{tabular}{|c|c|c|c|c|c|c|c|c|}
\hline Case no. ${ }^{\star}$ & $\begin{array}{c}\mathrm{IgG} \\
(\mathrm{mg} / 100 \mathrm{ml})\end{array}$ & $\begin{array}{c}\mathrm{IgA} \\
(\mathrm{mg} / 100 \mathrm{ml})\end{array}$ & $\begin{array}{c}\mathrm{IgM} \\
(\mathrm{mg} / 100 \mathrm{ml})\end{array}$ & Latext & SSC $\ddagger$ & ANAS & $\begin{array}{l}\text { Urinary } \\
\text { CMV }\end{array}$ & $\begin{array}{l}\text { Complement-fixing } \\
\text { antibody titres to } \mathrm{CMV}\end{array}$ \\
\hline $\begin{array}{c}\text { Mothers } \\
1 \\
2 \\
3 \\
4 \\
5 \\
6 \\
7 \\
8 \\
9 \\
10 \\
11 \\
12 \\
13 \\
\text { Infants } \\
1 \\
2 \\
3 \\
4 \\
5 \\
6 \\
7 \\
8 \\
9 \\
10 \\
11\end{array}$ & $\begin{array}{r}1480 \\
2360 \\
1180 \\
2060 \\
1320 \\
1480 \\
1480 \\
1400 \\
1650 \\
1480 \\
1320 \\
750 \\
1850 \\
\\
\\
1300 \\
1030 \\
2050 \\
1030 \\
470 \\
925 \\
380 \\
1850 \\
470 \\
590 \\
1480\end{array}$ & $\begin{array}{r}440 \\
190 \\
190 \\
130 \\
274 \\
286 \\
150 \\
232 \\
70 \\
162 \\
102 \\
162 \\
140 \\
\\
\\
237 \\
<32 \\
275 \\
65 \\
<32 \\
<32 \\
64 \\
64 \\
<32 \\
<32 \\
102\end{array}$ & $\begin{array}{r}104 \\
314 \\
72 \\
92 \\
192 \\
246 \\
63 \\
116 \\
140 \\
170 \\
118 \\
196 \\
132 \\
\\
\\
59 \\
59 \\
140 \\
59 \\
36 \\
66 \\
38 \\
59 \\
52 \\
46 \\
132\end{array}$ & $\begin{array}{r}0 \\
0 \\
0 \\
0 \\
0 \\
0 \\
0 \\
160 \\
0 \\
0 \\
0 \\
0 \\
0 \\
\\
\\
0 \\
0 \\
0 \\
0 \\
0 \\
0 \\
0 \\
0 \\
40 \\
0 \\
0 \\
0\end{array}$ & $\begin{array}{l}0 \\
0 \\
0 \\
0 \\
0 \\
0 \\
0 \\
0 \\
0 \\
0 \\
0 \\
0 \\
0 \\
\\
0 \\
0 \\
0 \\
0 \\
0 \\
0 \\
0 \\
4 \\
0 \\
0 \\
4\end{array}$ & $\begin{array}{r}0 \\
0 \\
0 \\
0 \\
0 \\
0 \\
0 \\
0 \\
0 \\
0 \\
0 \\
0 \\
0 \\
\\
\\
0 \\
0 \\
16 \\
0 \\
0 \\
0 \\
0 \\
0 \\
0 \\
0 \\
0\end{array}$ & $\begin{array}{l}+ \\
0 \\
+ \\
+ \\
+ \\
+ \\
+ \\
+ \\
+ \\
+ \\
+ \\
+ \\
+\end{array}$ & $\begin{array}{r}32 \\
32 \\
32 \\
16 \\
32 \\
128 \\
128 \\
256 \\
128 \\
64 \\
512 \\
256 \\
128 \\
\\
\\
32 \\
32 \\
<8 \\
16 \\
8 \\
128 \\
32 \\
128 \\
64 \\
32 \\
64\end{array}$ \\
\hline
\end{tabular}

* Mothers and infants 1-8 related and studied simultaneously.

+ Reciprocal of latex agglutination titre.

$\ddagger$ Reciprocal of sensitized sheep cell titre.

SAntinuclear antibody.

raised levels of $\operatorname{IgG}$ and $\operatorname{IgM}$ together with a positive heterophile titre of $1: 8$, a third mother (Case 4) had a raised IgG level as her sole abnormality. All subjects, with the exception of 1 infant, showed a positive antibody response to CMV ranging from serum titres of $1: 8$ to $1: 512$. In one instance a mother was excreting virus but the baby (Case 7) was not. This was probably an example of re-activation of latent infection in the mother during pregnancy; the baby's antibodies were probably maternal in origin.

\section{Discussion}

This study indicates that immunological abnormalities are sparse and slight in young infants and in their mothers who are asymptomatic excretors of CMV. In distinct contrast to post-perfusion CMV disease and spontaneous CMV mononucleosis, no cryoglobulins were found, nor were high titres of humoral autoantibodies detected. Moreover, modest rises of serum immunoglobulins (IgG and/or IgM) were detected in only 2 infants and 2 mothers. Raised serum IgM levels have been previously noted in such infants (McCracken and Shinefield, 1965).
The reasons for the serological differences between our subjects compared to those reported in patients with symptomatic CMV disease are not clear. However, several explanations are possible. First, CMV disease presenting as post-perfusion syndrome or as atypical mononucleosis might be due to a different strain of virus from that causing asymptomatic infections in pregnant women and newborn infants. Secondly, overt disease in adulthood might represent a second exposure to the virus even in those cases with an apparently primary antibody response, or reactivation of a latent virus infection which activates an autoimmune humoral response in the host. Indeed, there is some evidence to suggest that in certain patients the post-perfusion syndrome represents reactivation of a pre-existing latent infection (Kantor and Johnson, 1970) and that the clinical manifestations are precipitated by the extra-corporeal circulation and attendant massive transfusion (Weller, 1971). The CMV carrier state of some of our patients possibly follows first exposure to the organism. However, recent observations suggest that the cervical CMV infection observed during gestation might represent reactivation of the virus in some instances (Reynolds, 
Stagno, and Alford, 1972). Lastly, the asymptomatic carrier state may be too localized to evoke an abnormal host response. There certainly was no evidence of generalized CMV-induced anergy such as is seen in some viral infections (Salaman, 1970). Thus, many of the mothers and infants studied here showed a high titre serum anti-CMV antibody response.

\section{Summary}

Serum immunological abnormalities were sought in 13 mothers and 11 infants with asymptomatic cytomegalovirus (CMV) infection. Only a few minor abnormalities were detected, contrasting sharply with the well-described abnormalities in patients with post-perfusion or adult CMV syndrome.

\section{REFERENCES}

Kantor, G. L., Goldberg, L. S., Johnson, B. L., Derechin, M. M. and Barnett, E. V. (1970). Immunologic abnormalities induced by postperfusion cytomegalovirus infection. Annals of Internal Medicine, 73, 553.

Kantor, G. L., and Johnson, B. L. (1970). Cytomegalovirus infection associated with cardiopulmonary bypass. Archives of Internal Medicine, 125, 488.

Klemola, E., von Essen, R., Wager, O., Haltia, K., Koivuniemi, A., and Salmi, I. (1969). Cytomegalovirus mononucleosis in previously healthy individuals: five new cases and follow-up of 13 previously published cases. Annals of Internal Medicine, 71, 11.

McCracken, G. H., and Shinefield, H. R. (1965). Immunoglobulin concentrations in newborn infants with congenital cytomegalic inclusion disease. Pediatrics, 36, 933.

Reynolds, D. W., Stagno, S., and Alford, C. A. (1972). The relation between cervical and perinatal cytomegalovirus (CMV) infections. (Abst.) Pediatric Research, 6, 391.

Salaman, M. H. (1970). Immunosuppressive effects in infection. Proceedings of the Royal Society of Medicine, 63, 11.

Stern, H., and Elek, S. D. (1965). The incidence of infection with cytomegalovirus in a normal population. A serological study in Greater London. Fournal of Hygiene, 63, 79.

Stern, H., and Tucker, S. M. (1965). Cytomegalovirus infection in the newborn and in early childhood: three atypical cases. Lancet, 2, 1268.

Stiehm, E. R., and Fudenberg, H. H. (1966). Serum levels of immune globulins in health and disease: a survey. Pediatrics, 37, 715.

Wager, O., Räsänen, J. A., Hagman, A., and Klemola, E. (1968) Mixed cryoimmunoglobulinaemia in infectious mononucleosis and cytomegalovirus mononucleosis. International Archives of Allergy and Applied Immunology, 34, 345.

Weller, T. H. (1971). The cytomegaloviruses: ubiquitous agents with protean clinical manifestations. New England fournal of Medicine, 285, 203.

R. Bluestone, ${ }^{\star}$ L. S. Goldberg, S. M. Tucker, and H. STERN

VA Wadsworth Hospital and UCLA School of Medicine, Los Angeles; Hillingdon Hospital, Middlesex; and St. George's Hospital Medical School, London.

*Correspondence to Dr. R. Bluestone, Rheumatology Section, VA Wadsworth Hospital, Los Angeles, California 90073, U.S.A.

\section{Hyperglycaemia in hyperosmolar dehydration}

Hyperosmolar dehydration is a well recognized clinical state in which hyperglycaemia has been noted as a coincidental finding. Hitherto this hyperglycaemia has been considered of little importance, but we wish to report 6 cases where it was a prominent feature and discuss its possible aetiology and significance, stressing the dangers of insulin therapy in such patients.

\section{Materials and methods}

The ages of our patients ranged from 11 days to 22 months. Gastroenteritis was the precipitating illness in all. Intake of carbohydrate had not been excessive and none had a family history of diabetes mellitus. The Table gives the initial laboratory findings.

The clinical management was not identical in each case since several hospitals were involved, particularly in Cases 1, 2, and 3. All received intravenous fluids.

Hyperosmolar dehydration is a well-recognized clinical entity in paediatrics, but the finding of hyperglycaemia was unexpected and it confused the initial diagnosis in Cases 1, 2, and 3 in whom diabetes mellitus was suspected and insulin therapy instituted. In Case 2 this produced hypoglycaemic convulsions (venous blood glucose $16 \mathrm{mg} / 100 \mathrm{ml}$ ) which were corrected by an intravenous injection of $20 \mathrm{ml} 20 \%$ glucose. Case 3 died 13 hours after admission but was not hypoglycaemic at any time: necropsy confirmed gastroenteritis; pancreatic histology was normal and death was attributed to 'metabolic causes'. Cases 4, 5, and 6 received no insulin. Of the 5 survivors, 4 were considered physically and mentally normal after follow-up periods ranging from 6 months to 3 years. Case 5 is physically normal but may be slightly handicapped intellectually.

\section{Discussion}

Diabetes mellitus is rare in infancy and certainly less frequent than hyperosmolar dehydration. A transient diabetic state in infancy has been described (Hutchison, Keay, and Kerr, 1962), but our patients did not show the typical features of this condition, namely dysmaturity, polyuria, gross clinical dehydration, the need for insulin therapy for some months, and poor psychomotor development. Hyperosmolar nonketotic diabetes is well known, but our patients did not have diabetes mellitus. Hyperglycaemia occurs in cerebral abnormalities, e.g. head injury, epilepsy, encephalitis, tumour, abscess, and in asphyxia, acidosis, burns, and ether anaesthesia.

Hyperglycaemia has been recorded in nondiabetic infants with hyperosmolar dehydration (Bruck, Abal, and Aceto, 1968; Burman and 